\title{
The Investigation of the Relationship between Teachers' Creative Thinking Tendencies and Individual Innovativeness Characteristics
}

\begin{tabular}{ccc}
\hline Article Type & Received Date & Accepted Date \\
Research & 27.06 .2018 & 14.11 .2019 \\
\hline
\end{tabular}

\section{İshak Kozikoğlu**}

\section{Bedirhan Ahmet Küçük ${ }^{* *}$}

\begin{abstract}
This study aims to investigate the relationship between teachers' creative thinking tendencies and individual innovativeness characteristics. This study used correlational survey model and was carried out with 283 teachers from different branches working in Turkey. "Critical Thinking Dispositions Scale" developed by Özgenel and Çetin (2017), "Individual Innovativeness Scale" adapted into Turkish by Kılıçer and Odabaşı (2010) were used as data collection tools. In data analysis; descriptive statistics (arithmetic mean and standard deviation), differential statistics ( $\mathrm{t}$ test and ANOVA), Pearson Product Moments Correlation Coefficient and simple linear regression analysis were used. The results show that teachers' creative thinking tendencies are at high level and individual innovativeness characteristics are in the "early adopters" and "early majority" categories. While teachers' creative thinking tendencies and individual innovativeness characteristics did not change significantly according to gender, it was determined that teachers who had 16 years and more experience had a higher level of creative thinking tendencies and individual innovative scores than teachers who had between 1-5 years. A moderate, positive and significant relationship was found to be between teachers' creative thinking tendencies and individual innovativeness characteristics.
\end{abstract}

Keywords: Creativity, creative thinking, innovation, individual innovativeness.

\footnotetext{
** Corresponding Author: Assoc. Prof. Dr., Van Yüzüncü Y1l University, Department of Educational Sciences, Division of Curriculum and Instruction, Van, Turkey. E-mail: ishakkozikoglu@yyu.edu.tr, https://orcid.org/ 0000-0003-3772-4179

*** Master Student, Van Yüzüncü Yıl University, Instutue of Educational Sciences, Department of Computer Education and Instructional Technology, Van, Turkey. E-mail: bedirhankucuk@gmail.com, https://orcid.org/0000-0002-7802-7380
} 


\title{
Öğretmenlerin Yaratıcı Düşünme Eğilimleri ile Bireysel Yenilikçilik Özellikleri Arasındaki İlişkinin İncelenmesi
}

\begin{tabular}{ccc}
\hline Makale Türü & Başvuru Tarihi & Kabul Tarihi \\
Araştırma & 27.06 .2018 & 14.11 .2019 \\
\hline
\end{tabular} \\ İshak Kozikoğlu** \\ Bedirhan Ahmet Küçük** \\ $\ddot{O} \mathbf{z}$
}

\begin{abstract}
$\mathrm{Bu}$ çalışma, öğretmenlerin yaratıcı düşünme eğilimleri ile bireysel yenilikçilik özellikleri arasındaki iliş̧kiyi incelemeyi amaçlamaktadır. Çalışmada ilişkisel tarama deseni kullanılmıştır. Araştırma, Türkiye'de farklı branşlarda görev yapan 283 öğretmen ile gerçekleştirilmiştir. Araştırmada, Özgenel ve Çetin (2017) tarafindan geliştirilen "Yaratıcı Düşünme Eğilimleri Ölçeğì", K1liçer ve Odabaşı (2010) tarafindan Türkçe'ye uyarlanan "Bireysel Yenilikçilik Ölçeği," kullanılmıştır. Verilerin analizinde; betimsel istatistikler (aritmetik ortalama ve standart sapma), fark analizleri ( $\mathrm{t}$ testi ve ANOVA), Pearson Çarpım Momentler Korelasyon Katsayısı ve basit doğrusal regresyon analizi kullanılmıştır. Sonuçlar, öğretmenlerin yaratıcı düşünme eğilimlerinin yüksek, bireysel yenilikçilik özelliklerinin ise çoğunlukla "öncü" ve "sorgulayıcı" olduğunu ortaya koymuştur. Öğretmenlerin yaratıı düşünme eğilimleri ve bireysel yenilikçilik özellikleri cinsiyete göre anlamlı farklılık göstermezken, 16 yıl ve üzeri deneyimi olan öğretmenlerin 1-5 yıl arasında deneyime sahip olan öğretmenlere göre yaratıcı düşünme eğilimlerinin ve bireysel yenilikçi puanlarının daha yüksek düzeyde olduğu belirlenmiştir. Öğretmenlerin yaratıcı düşünme eğilimleri ile bireysel yenilikçilik özellikleri arasında orta düzeyde, pozitif ve anlamlı bir ilişkinin olduğu sonucuna varılmıştır.
\end{abstract}

Anahtar Sözcükler: Yaratıcılık, yaratıcı düşünme, yenilik, bireysel yenilikçilik.

\footnotetext{
** Sorumlu Yazar: Doç. Dr., Van Yüzüncü Yıl Üniversitesi, Eğitim Bilimleri Bölümü, Eğitim Programları ve Öğretim Anabilim Dalı, Van, Türkiye. E-posta: ishakkozikoglu@yyu.edu.tr, https://orcid.org/0000-0003-3772-4179

*** Yüksek Lisans Öğrencisi, Van Yüzüncü Yıl Üniversitesi, Eğitim Fakültesi, Bilgisayar ve Öğretim Teknolojileri Bölümü, Van, Türkiye. E-posta: bedirhankucuk@gmail.com, https://orcid.org/0000-0002-7802-7380
} 


\section{Introduction}

In this era, we are experiencing new developments every day, especially with the progress of science and technology, and new ideas are being put forward. People can follow the developments that happen in everywhere in the world thanks to these developments. States, on the other hand, expect the individuals in the society to think and implement their ideas with respect to the requirements of era. In order to produce something new, it is necessary to be prepared to be different, to oppose traditional ideas, which means people need to have special courage for it (Emir, Erdoğan and Kuyumcu, 2007). People are productive. The main way to produce something unique is to think creatively and to be innovative. In this respect, Doğan (2016) stated that the education system itself should be reorganized in order to get the students develop their potentials and to have an active responsibility in the development of the country by acquiring the skills of creative thinking, relational thinking, scientific thinking and reasoning. It should not be forgotten that the teachers should have these features as well as the rearrangement of the education system and teaching. The reason for this is the fact that it is the school in which students need to acquire higher order thinking skills such as critical thinking, problem solving and creative thinking in order to develop their individual innovative features and to able to keep up with the changes and the people who will provide this should be the teachers.

\section{Creative Thinking}

Although the concept of creativity has been defined by many researchers, there is no single certain definition of creativity. Young (1985) defines creativity as the paradoxical integration of doing and existence. According to Karataş and Özcan (2010) creativity is not just to create an original product, but also to synthesize new knowledge from existing information, creating different solutions to problems, adapting easily to new situations, and thinking the functions of objects extraordinarily. While Kiesswetter (1983) describes creativity as the development of flexible thinking skills (Meissner, 1999; Cited in Gür and Kandemir, 2006), Doğan (2016) describes it as the skill, attitude or behavior of thinking differently from everyone else. In this case, it is seen that the concepts such as originality, synthesis, development of solutions, flexible thinking, and difference come into prominence in the concept of creativity.

On the other hand, creative thinking is defined by Yenilmez and Yolcu (2007) as a method of thinking that enables the emergence of original ideas, which are inventors, seeking for innovation or bringing new solutions to old problems and as a phenomenon that must be found and developed in the information era. Similarly, creative thinking is expressed by Korucu and Olpak (2015) as the skills of complexity management, curiosity, self-management, creativity, risk taking, higher-order thinking and logical reasoning skills. Therefore, creative thinking can be defined as the ability to examine the events extraordinarily and to express original opinions.

According to the literature, it is concluded that characteristics of creative individuals are listed as the individuals who can produce different and diverse ideas, are no afraid of making mistakes, can take risks, are curious, can look at the events from different points of view (Doğan, 2016), can give original responses instead of ordinary answers (Yaman and Yalçın, 2005), are open to new ideas, whose energy is high and natural, are capable of producing solutions to unexpected situations (Emir and Bahar, 2003), are not inclined to get the approval of others and are fond of freedom (Birişçi ve Karal, 2015).

The potential of creativity is present in all human beings and this potential can be developed with education (Aslan, 2002; Taylor and Sacks, 1981; Ülger, 2016). Accordingly, regardless of whether the level of intelligence is too high, it is accepted that creativity is an existing feature of anyone. Several factors influence not to come out or not developing creativity in the individuals. These factors can stem from the environment, from oneself, family or the teacher. According to Doğan (2016), teacherbased factors can be listed as not giving importance to the critical thinking in the classroom, discouraging the students, insecurity, excessive criticism, inconsistency in behavior, lack of enthusiasm, being dogmatic, harsh and inadequate, not supporting out of class discussion and giving opportunity to speak, deficiencies of the knowledge and skills in implementation of teaching 
techniques or methods. Then, it can be stated that the teachers play a critical role in acquiring the creative thinking skills of the students.

Özerbaş (2011) points out that in order to be a creative model in class, teachers should primarily know what creative thinking is, its definition, its, examples, the elements of creativity which are originality, flexibility, fluency, interpretation, multidimensional thinking and unification. When we think of today's societies, we can understand that it is required to organize learning environments which are interactive, contemporary and enable the students to think, produce and be creative. It is not aimed to educate students who only "know" as they are in traditional education understanding. It is one of the most crucial objectives of today's educational systems to train multifaceted, creative individuals having ability to easily adapt to new situations, comment on the events from different points of view, and offer various solutions to the problems encountered. Therefore, there is a need for teachers who are able to organize teaching-learning environments that enable them to grow up to be innovative, productive, creative, and accountable for the use of higher order thinking skills effectively. When it is considered that first of all, teachers should be creative and innovative in order for these to happen, it clearly shows up the importance of determining the teachers' creative thinking tendencies and innovativeness characteristics.

\section{Individual Innovativeness}

Currently, as in the past, a new one is added to the innovations every day, and people continue to adapt to it. The effort that individuals have made in response to these innovations is the inevitable reality of our day in order that life can continue. According to Akçöltekin (2017), individual innovativeness refers to the situations such as risk taking, adaptation, acceptance, tolerance and openness to new experiences. Kilıçer (2011) defines individual innovativeness as an individual's willingness to be innovative, adopt it and have a favorable outlook on innovation, its use and utilization. Işık and Türkmendağ (2016), on the other hand, express the concept of individual innovativeness as "the sense of being perceived as new for any product, service or opinion by a person, and interpret it as a dicipline, ability of learning and implementation. In this case, individual innovativeness can be seen as positive reactions of individuals towards innovation. Also, as expressed in the literature, people with individual innovative characteristics can be treated into five different groups. According to Rogers (2003) these groups can be classified as follows:

- Innovators: They are the individuals who can cope with various uncertainties, are willing to try new ideas and possess role of transmitting new concepts and innovations to the social system.

- Early Adopters: They are the ones who are consulted about innovations by other individuals in the society. They are technology-oriented individuals who guide and reduce uncertainty on innovations.

- Early Majority: They are the ones who are cautious towards innovations and do not seem very willing to take risks.

- Late Majority: They are the ones who are skeptical and reserved about innovation. Accepting an innovation for them is a requirement after the acceptance of the majority in the society.

- Laggards: They are the last individuals who accept the innovations.

Innovative teacher is expressed as the individuals who can improve their own skills in their area, increase the activities that students can participate with respect to the needs of developing teaching and learning strategies, apply various methods/techniques to enhance student involvement, try new methods and approaches in presenting information, develop innovative skills by changing their habits (Ritchhart, 2004; Cited in Korucu ve Olpak, 2015). Akçöltekin (2017) notes that learners, employees and citizens' innovative skills and their positive attitudes towards innovativeness can be improved through education, and new and more influential educational approaches, methods and technologies can be created through innovativeness. Çuhadar, Bülbül and Ilgaz (2013) state that it is necessary to train innovator prospective teachers who can adapt to innovations and utilise technological opportunities in combination with pedagogical approaches. Thus, teacher competencies should be updated within the context of information society's needs. It may be said that teachers need to employ various methods, techniques and practices with an innovative spirit in order to create an effective 
teaching process. In this respect, it seems that it is necessary to determine the innovative characteristics of the teachers being one of the most crucial actors of the education system.

\section{The Aim and Importance of the Study}

This study aims to determine the relationship between teachers' creative thinking tendencies and individual innovativeness characteristics. Based on this general purpose, the following questions are addressed:

1. At what level are teachers' creative thinking tendencies?

2. What are teachers' individual innovativeness characteristics?

3. Do teachers' creative thinking tendencies and individual innovativeness characteristics differ significantly according to gender and professional experience?

4. Is there a significant relationship between teachers' creative thinking tendencies and individual innovativeness characteristics?

5. Do teachers' individual innovativeness characteristics predict their creative thinking tendencies significantly?

There are many studies in the literature on creative thinking (Emir, Erdoğan and Kuyumcu, 2007; Karataş and Özcan, 2010; Özerbaş, 2011; Tok and Sevinç, 2012; Yaman and Yalçın, 2005; Yenilmez and Yolcu, 2007) and individual innovativeness (Akçöltekin, 2017; Çuhadar, Bülbül and Ilgaz, 2013; Işı1k and Türkmendağ, 2016; Kılıç, 2015; Kılıçer and Odabaşı, 2010; Korucu and Olpak, 2015; Örün, Orhan, Dönmez and Kurt, 2015; Özgür, 2013; Y1lmaz Öztürk and Summak, 2014). In these studies, these concepts were examined separately, and no studies examining the relationship between these two concepts were found. This study has importance in terms of being the first study in the literature associating these two concepts by determining the relationship between teachers' creative thinking tendencies and individual innovativeness characteristics. In addition, having an idea about current teachers' individual innovativeness characteristics and creative thinking tendencies, with the intention of creating a contemporary, productive and thinking society, will shed light on the future studies. It is considered that this study will contribute to the target literature in terms of reflecting the effect of innovativeness characteristics on creative thinking by determining the degree to which teachers' individual innovativeness characteristics predict their creative thinking tendencies.

\section{Method}

\section{Research Model}

This study used correlational survey model. In correlational survey model, it is aimed to determine the level and existence of change among two or more variables (Karasar, 2015). As the relationship between teachers' creative thinking tendencies and individual innovativeness characteristics is examined in this study, it is thought that the use of correlational survey model is suitable for the purpose of this study.

\section{Study Group}

The study group of this study comprises 283 teachers working in different cities of Turkey. Research data were collected through Google Forms being one of the most widely used tools today. The scales on the Google Form were posted via social networks, forum sites, e-mail, WhatsApp by using an online link and the data were collected online. Therefore, in order to determine the study group, convenience sampling method was used on the basis of volunteerism and easy accessibility. In convenience sampling, the researcher works on the group that is easy to access, so this method gives practicality to the study (Yıldırım and Şimşek, 2013).

In this study, 83 participants $(29.3 \%)$ are male and $200(70.7 \%)$ are female. 122 teachers $(\% 43.1)$ have between 1-5 years, 47 teachers $(16.6 \%)$ have between 6-10 years, 52 teachers $(18.4 \%)$ have between 11-15 years and 62 teachers (21.9\%) have 16 years and over professional experience. 


\section{Data Collection Tools}

Creative Thinking Tendency Scale: 5-point Likert-type scale, developed by Özgenel and Çetin (2017), comprise 25 items and six sub-dimensions that are "searching for innovation", "courage", "self-discipline", "curiosity", "doubting" and "flexibility". The Cronbach Alpha coefficient of the scale was calculated as .87 , which was found as .89 in this study. These values indicate that the data obtained from the scale is reliable.

Individual Innovativeness Scale: 5-point Likert-type scale, developed by Hurt, Joseph and Cook (1977) and adapted into Turkish by Kılıçer and Odabaşı (2010), comprise 20 items that are 12 positive, 8 negative. The Cronbach Alpha coefficient of the scale was calculated as .89 , which was found as .71 in this study. These values indicate that the data obtained from the scale is reliable.

\section{Data Analysis}

The arithmetic mean and standard deviation values were examined to determine teachers' creative thinking tendencies. These values were evaluated as 'very low' between 1-1.79, 'low' between 1.80-2.59, 'moderate' between 2.60-3.39, 'high' between 3.40-4.19, 'very high' between 4.20-5.00. In order to determine teachers' individual innovative characteristics; those whose score is above 80 were considered as innovators, those whose score is between 69-80 were considered as early adopters, those whose score is between 57-68 were considered as early majority, those whose score is between 46-56 were considered as late majority and those whose score is below 46 were considered as laggards. In general, those whose score is above 68 were considered as highly innovative, those whose score is below 64 were considered as low in innovativeness (Kilıçer and Odabaşı, 2010).

The normality test was conducted to determine whether the scale scores varied according to teachers' gender and professional experience. Histogram graphs of dependent variables were examined for univariate normality. Furthermore, skewness and kurtosis values were also examined. As a result, skewness values of dependent variables in creative thinking tendencies scale ranged from 0.325 to 0.970 , and kurtosis values ranged from 0.154 to 0.780 ; while skewness values of dependent variables in individual innovativeness scale ranged from -0.214 to 0.650 , and kurtosis values ranged from -0.055 to 0.680 . In this case, it was assumed that the data show normal distribution as the skewness and kurtosis coefficients for the scores of the dependent variables were within \pm 1 range and histogram graphs display normality (Büyüköztürk, 2016). As normal distribution of the data was ensured, t-test was used for the gender and ANOVA was used for professional experience. In case of significant difference in ANOVA test, Scheffe test was used as one of the post-hoc tests. Also, effect size (eta squared) values were examined to determine how effective independent variable is on the dependent variable and these values were interpreted as low level effect between " $0.01 \leq \eta 2<0.06$ ", moderate level effect between " $0.06 \leq \eta 2<0.14$ " and high level effect " $\eta 2 \geq 0,14$ " (Büyüköztürk, 2016). Pearson Product Moment Correlation Coefficients were examined to determine the relationship between two variables. In addition, simple linear regression analysis was used to determine the extent to which teachers' individual innovativeness characteristics predict their creative thinking tendencies.

\section{Results}

Arithmetic mean and standard deviation values concerning the first sub-problem are presented in Table 1:

\section{Table 1}

The Arithmetic Mean and Standard Deviation Values Concerning CreativeThinking Scale

\begin{tabular}{lcc}
\hline Scale and sub-dimensions & $\bar{X}$ & $\boldsymbol{s}$ \\
\hline Creative thinking (Total) & 4.13 & 0.38 \\
Self-discipline & 4.00 & 0.51 \\
Searching for innovation & 4.12 & 0.44 \\
Courage & 3.91 & 0.59 \\
Curiosity & 4.39 & 0.48 \\
Doubting & 4.27 & 0.52 \\
Flexibility & 4.31 & 0.45 \\
\hline
\end{tabular}


Table 1 shows that creative thinking tendencies of teachers in total scale $(\bar{X}=4.13)$ and in the sub-dimensions of self-discipline ( $\left.{ }^{X}=4.00\right)$, searching for innovation $\left({ }^{X}=4.12\right)$, and courage ( $=3.91)$ are at high level, in the sub-dimensions of curiosity ( $\left.{ }^{X}=4.39\right)$, doubting $\left({ }^{X}=4.27\right)$ and flexibility $\left({ }^{X}=4.31\right)$ are at very high level. In other words, teachers were found to have creative thinking skills to a great extent.

The individual innovativeness characteristics of the teachers concerning the second sub-problem are presented in Table 2:

\section{Table 2}

The Individual Innovativeness Characteristics of the Teachers

\begin{tabular}{lcc}
\hline $\begin{array}{l}\text { Individual innovativeness } \\
\text { characteristics }\end{array}$ & Number $(\mathbf{N})$ & $\begin{array}{l}\text { Percentage } \\
(\%)\end{array}$ \\
\hline Innovator & 54 & 19.1 \\
Early Adopter & 131 & 46.3 \\
Early Majority & 88 & 31.1 \\
Late Majority & 9 & 3.2 \\
Laggard & 1 & 0.3 \\
\hline
\end{tabular}

Table 2 shows that 54 teachers (\%19.1) are innovator, $131(46.3 \%)$ are early adopter, $88(31.1 \%)$ are early majority, $9(3.2 \%)$ are late majority, and $1(\% 0.3)$ is laggard. In other words, it turns out that 185 of the teachers can be considered as innovator and 98 of them can be regarded as low in innovativeness.

The t-test results on whether teachers' creative thinking tendencies and individual innovativeness characteristics differ according to gender concerning the third sub-problem are presented in Table 3.

\section{Table 3}

The t-test Results of Teachers' Creative Thinking Tendencies and Individual Innovativeness Characteristics According To Gender

\begin{tabular}{llcllllll}
\hline Scales & Gender & $\mathbf{N}$ & $\bar{X}$ /Score & S & sd & t & p & $\begin{array}{l}\text { Eta- } \\
\text { squared }\end{array}$ \\
\hline Creativity & Female & 200 & 4.16 & 0.38 & 281 & 1.80 & .074 & .011 \\
& Male & 83 & 4.07 & 0.38 & & & & \\
\hline Individual & Female & 200 & 72.18 & 9.14 & 281 & 0.89 & .376 & .003 \\
Innovativeness & Male & 83 & 71.12 & 9.05 & & & & \\
\hline
\end{tabular}

As seen in Table 3, it was found that the teachers' creative thinking tendencies $\left(\mathrm{t}_{(281)}=1.80\right.$, $\mathrm{p}>.05)$ and individual innovativeness characteristics $\left(\mathrm{t}_{(281)}=0.89, \mathrm{p}>.05\right)$ did not differ significantly according to gender. The results of the ANOVA test on whether teachers' creative thinking tendencies and individual innovativeness characteristics differ according to professional experience are presented in Table 4.

\section{Table 4}

ANOVA Results of Teachers' Creative Thinking Tendencies and Individual Innovativeness According to Professional Experience

\begin{tabular}{|c|c|c|c|c|c|c|c|c|c|c|c|c|}
\hline \multicolumn{5}{|c|}{ Descriptive Statistics } & \multicolumn{8}{|c|}{ ANOVA Results } \\
\hline Scales & Experience & $N$ & $\bar{X}$ & $S$ & $\begin{array}{l}\text { Source } \\
\text { of } \\
\text { variance }\end{array}$ & $\begin{array}{l}\text { Sum of } \\
\text { squares }\end{array}$ & $s d$ & $\begin{array}{l}\text { Mean of } \\
\text { squares }\end{array}$ & $F$ & $p$ & $\begin{array}{l}\text { Eta- } \\
\text { squ. }\end{array}$ & Diff. \\
\hline \multirow{5}{*}{ Creativity } & $1-5$ years & 122 & 4.03 & 0.38 & Between & 3.404 & 3 & 1.135 & 8.399 & .003 & .083 & $4>1$ \\
\hline & $6-10$ years & 47 & 4.11 & 0.39 & groups & & & & & & & \\
\hline & $11-15$ years & 52 & 4.17 & 0.32 & Within & 37.695 & 279 & .135 & & & & \\
\hline & 16 years/over & 62 & 4.31 & 0.36 & groups & & & & & & & \\
\hline & & & & & Total & 41.099 & 282 & & & & & \\
\hline Individual & $1-5$ years & 122 & 70.27 & 8.86 & Between & 1001.975 & 3 & 333.39 & 4.157 & .007 & .043 & $4>1$ \\
\hline
\end{tabular}




\begin{tabular}{lllllllll}
\hline Innovative & 6-10 years & 47 & 70,77 & 10.31 & groups & & \\
ness & 11-15 years & 52 & 73.04 & 7.99 & Within & 22414.92 & 279 & \\
& 16 years/over & 62 & 74.88 & 8.85 & $\begin{array}{l}\text { groups } \\
\text { Total }\end{array}$ & 23416.89 & 282 & 80.340 \\
& & & & & & & \\
\hline
\end{tabular}

$p<.05$, Note: 1- "1-5 years", 2- "6-10 years", 3- "11-15 years", 4- "16 years and over"

According to Table 4, a significant difference was determined in teachers' creative thinking tendencies $\left(\mathrm{F}_{(3,279)}=8,399, \mathrm{p}<.05\right)$ and individual innovativeness characteristics $\left(\mathrm{F}_{(3,279)}=4,157\right.$, $\mathrm{p}<.05)$ according to professional experience between the teachers who have professional experience over 16 years and 1-5 years professional experience in favor of the teachers who have professional experience over 16 years. When examined by effect size, it is seen that professional experience has moderate level of effect on creative thinking tendencies of teachers $(0.06 \leq \eta 2<0.14)$, while it has low level of effect on individual innovativeness of teachers $(\eta 2<0.06)$.

Pearson Product Moments Correlation Coefficients concerning the fourth sub-problem are presented in Table 5 .

\section{Table 5}

Pearson Product Moments Correlation Coefficients Concerning the Variables Included in the Study

\begin{tabular}{lcc}
\hline Variables & Individual Innovativeness & Creativity \\
\hline Individual Innovativeness & 1.00 & \\
Creativity & $.622^{* *}$ & 1.00 \\
\hline$p<.05^{*}, p<.01^{* *}$ & &
\end{tabular}

According to Table 5; a moderate, positive and significant relationship was determined between teachers' creative thinking tendencies and individual innovativeness characteristics $(r=.622 ; p<.01)$. In other words, as teachers' individual innovativeness increases, their creative thinking tendencies increase, as well. Table 6.

The results of simple linear regression analysis concerning the fifth sub-problem are presented in

\section{Table 6}

The Results of Simple Linear Regression Analysis for Prediction of Teachers' Creative Thinking Tendencies

\begin{tabular}{|c|c|c|c|c|c|c|c|c|c|}
\hline Regression Results & & & & ANOVA Re & & & & & \\
\hline $\begin{array}{l}\text { Predictive } \\
\text { Variable }\end{array}$ & $B$ & $\begin{array}{l}\text { Predictive } \\
\operatorname{Power}(\boldsymbol{R})\end{array}$ & $\begin{array}{l}\text { Explained } \\
\text { Variance } \\
\left(R^{2}\right)\end{array}$ & $\begin{array}{l}\text { Source of } \\
\text { variance }\end{array}$ & $\begin{array}{l}\text { Sum of } \\
\text { squares }\end{array}$ & sd & $\begin{array}{l}\text { Mean of } \\
\text { squares }\end{array}$ & $F$ & $p$ \\
\hline $\begin{array}{l}\text { Individual } \\
\text { Innovativeness }\end{array}$ & .622 & .622 & .387 & $\begin{array}{l}\text { Regression } \\
\text { Residual }\end{array}$ & $\begin{array}{l}15.915 \\
25.184\end{array}$ & $\begin{array}{l}1 \\
281\end{array}$ & $\begin{array}{l}15.915 \\
.090\end{array}$ & 117.579 & .000 \\
\hline
\end{tabular}

Table 6 shows that teachers' individual innovativeness account for $38.7 \%\left(\mathrm{R}=.622 ; \mathrm{R}^{2}=.387\right)$ of the variance in teachers' creative thinking tendencies and the predictive power is significant $\left(\mathrm{F}_{(1,281)}=\right.$ $117.579, \mathrm{p}<.000)$. The results show that teachers' individual innovativeness scores are a significant predictor of their creative thinking tendencies.

\section{Discussion, Conclusion and Recommendations}

In this research, teachers' creative thinking tendencies and individual innovativeness characteristics were examined. One of the personal qualities and professional competencies that teachers should have is creativity (Çalışkan, Negiş-Işıık ve Saygın 2013; Tunca, Şahin, Oğuz ve Güner, 2015). In addition, teachers' creative thinking tendencies are crucial for students to develop creative thinking skills (Tok and Sevinç, 2012; Torrance, 1965). The results of this study concluded that teachers' creative thinking tendencies are at high level. These study results support similar study results in the literature. Parallel to this study results, Yildiz et al (2011) conducted a study on 
prospective teachers of physical education department and concluded that the perceptions of prospective teachers concerning creativity is at high level. Similarly, Aydoğdu and Yüksel (2013) found that creativity of prospective teachers are at moderate level and over. Runco and Johnson (2002) concluded that parents and teachers viewed creative tratits desirably. These results can be evaluated as a positive situation in terms of competences and qualifications of teachers in the $21 \mathrm{st}$ century.

Creativity and innovation within the skills of the 21 st century are the skills that should be possessed by the students. For this reason, it is expected that teachers should have competences related to these skills (Trilling and Fadel, 2009; Örün, Orhan, Dönmez and Kurt, 2015). The results of this study showed that the individual innovativeness characteristics of the teachers are mostly early adopters $(\mathrm{f}=131 ; \% 46.3)$ and early majority $(\mathrm{f}=88 ; \% 19.1)$. These results overlap with similar studies' results in the literature. In the studies conducted by Korucu and Olpak (2015), Çuhadar, Bülbül and Ilgaz (2013), Loogma, Kruusvall and Ümarik (2012) and Özgür (2013), the teachers were in the "early majority" category; it was concluded in the thesis of Köroğlu (2014) that pre-school teachers are "early adopters" and preschool prospective teachers are in the "early majority" category; Yılmaz Öztürk and Summak (2015) concluded that the teachers are mostly in the category of "early adopters" and "early majority". In the studies conducted with prospective teachers (Adigüzel et al, 2014; Deniz, 2016; Örün et al, 2015), it was defined that the majority of prospective teachers are in the category of "early majority". Therefore, it can be inferred that in the studies concerning individual innovativeness characteristics of teachers and prospective teachers, the characteristics of "early adopter" and "early majority" came to the forefront.

Considering similar research results in the literature and this study results, it can be said that teachers have the tendency to guide the individuals in society and use the technology but are not very willing to take risk. Similarly, in their study on ideal teacher qualifications, Özabacı and Acat (2005) emphasized teacher qualifications such as guiding, stimulating learners and being modern that a teacher should have. Similarly, in the study conducted by Kozikoğlu (2017) regarding ideal teacher qualifications with prospective teachers, two of the prominent categories concerning ideal teacher qualifications were found to be innovativeness and being guide. Lee (2011) conluded that innovativeness in teaching and integrating information technology into teaching has a positive effect on students' learning. Thus, in this study, it can be considered as a positive result because of the fact that even if approximately one in five $(19.1 \%)$ of the teachers seem not to be very willing to be innovative and take risks (early majority), about half $(46.3 \%)$ of the teachers have the tendency of guiding the individuals in the society on innovativeness and being prone to technology (early adopters). In addition, as those whose score is 68 and over in individual innovativeness scale are considered as innovator, those whose score is less than 64 are seen as low in innovativeness (Kiliçer and Odabaş1, 2010), it can be concluded that in general, $65.4 \%$ of the participants are innovator and $34.6 \%$ are low in innovativeness. In this case, more than half of the teachers in this study can be considered as innovator, however, it is noteworthy that about one third is low in innovativeness. In today's developing world, it is necessary to reduce this ratio for teachers in order to increase their qualifications and keep themselves up-to-date.

This study concluded that teachers' creative thinking tendencies and individual innovativeness characteristics do not differ significantly according to gender. According to professional experience, it was determined that teachers with professional experience over 16 years have a higher level of creative thinking tendencies and individual innovative scores than teachers with professional experience between 1-5 years. There are similar and different results in the literature. In parallel with this study results; it was determined in some studies that individual innovativeness characteristics do not differ significantly according to gender (Çuhadar et al, 2013; Kert and Tekdal, 2012; Kılıçer, 2011; Korucu and Olpak, 2015; Özgür, 2013) and in some studies individual innovativeness characteristics do not differ significantly according to gender and professional experience (Başaran and Keleş, 2015; Kılıç, 2015). On the other hand, in their study with educational administrators, Yılmaz and Beşkaya (2018) concluded their individual innovativeness scores do not differ significantly according to gender, but according to professional experience, their individual innovativeness scores were found to be in favor of the administrators having 1-5 years of managerial 
experience, unlike the results of this study. Similarly, Richardson-Kemp and Yan (2003) found that teachers with fewer years of teaching experience have higher scores on innovativeness. In their study conducted with the prospective classroom teachers, Gök and Erdoğan (2011) determined a significant difference in the individual innovativeness scores in favor of the females and female prospective teachers have higher levels of creative thinking than the males. Stoltzfus, Nibbelink, Vredenburg and Hyrum (2011) found that males outperformed the females in creativity. It hasn't been reached any study examining teachers' creative thinking tendencies according to professional experience. Concerning the results of this study, it can be said that female and male prospective teachers have similar creative thinking tendencies and individual innovativeness scores. It can be also said that teachers with higher professional experience have a higher level of creative thinking tendencies and higher individual innovativeness scores than teachers with less professional experience. Sönmez (2004) stated that each experience receive something from the previous ones and has an effect on the quality of following experiences. When considered in this context, higher level creative thinking tendencies and individual innovativeness scores of the teachers with 16 years professional experience and over can be evaluated as an expected result.

This study concluded a moderate, positive and significant relationship between teachers' creative thinking tendencies and individual innovativeness scores. Then, it can be concluded that as teachers' individual innovativeness scores increase, so does their creative thinking tendencies. Besides, it was defined that the individual innovativeness scores of the teachers explained more than one third $(38.7 \%)$ of the teachers' variance in their creative thinking tendencies. In this respect, it can be said that the individual innovativeness scores of the teachers are a significant predictor of teachers' creative thinking tendencies. When literature is examined, no study has been reached on the relationship between teachers' creative thinking tendencies and individual innovativeness characteristics. Duran and Saraçoğlu (2009) emphasized the fact that the process of innovation begins with a creative mind and the characteristics of creative and innovative individuals are basically similar to each other, although they have different ways of thinking. In addition, the characteristic of creative individuals are ordered as individuals who can produce different and diverse ideas, being curious, analyzing the facts from different views, thinking multidimensionally (Doğan, 2016), giving original answers rather than ordinary answers (Yaman and Yalçın, 2005), open to innovations and new ideas (Emir and Bahar, 2003). Ferrari, Cachia and Punie (2009) stated that creative thinking in education comprises understanding and awareness to new ideas, while innovation is the application of creative thinking process. In this respect, innovativeness is the element leading to creative thinking. Similarly, creative thinking is an important skill to promote educational innovation (Seechaliao, 2017). Hence, the close relationship between individual innovativeness and creative thinking tendencies in this study supports the relevant literature and can be regarded as an expected result.

In the light of these research results, teachers' creative thinking tendencies and individual innovativeness levels are promising for having a more original and entrepreneurial society with creative and innovative individuals in the future. However, it is necessary to create opportunities in which teachers can show and develop these creativity and innovative qualities. In addition, their creativity and innovativeness initiatives should be supported by their institutions. More studies can be conducted to determine the qualifications of current teachers. Following the determination of the deficiencies, it is suggested that these deficiencies can be eliminated with in-service trainings and various activities. This study is limited to scales as data collection tools, in future studies teachers' creative thinking tendencies and individual innovativeness can be examined more comprehensively by using various tests, interview form, etc. Furthermore, the predictors of critical thinking tendencies can be analyzed by including various variables such as critical thinking, metacognition, etc. 


\section{References}

Adıgüzel, A., Kaya, A., Balay, R., \& Göçen, A. (2014). The relationship between teacher candidates' individual innovativeness and their learning attitudes. Journal of National Education, 204, 135-154.

Akçöltekin, A. (2017). Investigation of the relationship between high school teachers' individual innovativeness perceptions and their attitudes towards educational research. Journal of Education, Theory and Practical Research, 3(1), 23-37.

Aslan, A. E. (2002). Örgütte kişisel gelişim [Personal development in the organization]. Ankara: Nobel Publications.

Aydoğdu, N., \& Yüksel, İ. (2013). The relationship between prospective mathematics teachers' beliefs and attitudes towards history of mathematics and their creativeness level. Journal of Research in Education and Teaching, 2(4), 186-194.

Başaran, S. D., \& Keleş, S. (2015). Who is innovative? Examination of teachers' innovativeness level. Hacettepe University Journal of Education, 30(4), 106-118.

Biriş̧̧i, S., \& Karal, H. (2015). Effect of collaborative studies on prospective teachers' creative thinking skills while designing computer based material. Ahi Evran University Kırşehir Journal of Education Faculty, 12(2), 203-219.

Büyüköztürk, Ş. (2016). Sosyal bilimler için veri analizi el kitabı [Data analysis for social sciences: Manual book]. Ankara: Pegem Academy Publications.

Çalışkan, M., Negiş Işık, A., \& Saygın, Y. (2013). Prospective teachers' perception of ideal teacher. Elementary Education Online, 12(2), 575-584.

Çuhadar, C., Bülbül, T., \& Ilgaz, G. (2013). Exploring of the relationship between individual innovativeness and techno-pedagogical education competencies of pre-service teachers. Elementary Education Online, 12(3), 797-807.

Deniz, S. (2016). Individualistic innovative characteristics of preservice teachers. Electronic Turkish Studies, 11(9), 267-278.

Doğan, N. (2016). Creative thinking and creativity. Pegem Citation Index, 5, 167-198.

Duran, C., \& Saraçoğlu, M. (2009). The relationship between innovation and creativity and development of innovation process. Management and Economy: Journal of Celal Bayar University Faculty of Economics and Administrative Sciences, 16(1), 57-71.

Emir, S., \& Bahar, M. (2003). Teacher and student opinions about creativity. Abant İzet Baysal University Journal Social Sciences Institue.

Emir, S., Erdoğan, T., \& Kuyumcu, A. (2007). The relationship between creative thinking levels and socio-cultural characteristics of Turkish language teaching students. HAYEF: Journal of Education, 4(1), 73-87.

Ferrari, A., Cachia, R., \& Punie, Y. (2009). Innovation and creativity in education and training in the EU member states: Fostering creative learning and supporting innovative teaching - literature review on innovation and creativity in E\&T in the EU member states (ICEAC). Luxembourg: Office for Official Publications of the European Communities.

Gök, B., \& Erdoğan, T. (2011). The investigation of the creative thinking levels and the critical thinking disposition of pre-service elementary teachers. Journal of Faculty of Educational Sciences, 44(2), 29-51.

Gür, H., \& Kandemir, M . (2006). Creativity and mathematics education. Elementary Education Online, 5(1), 65-72.

Hurt, H. T., Joseph, K., \& Cook, C. D. (1977). Scales for the measurement of innovativeness. Human Communication Research, 4(1), 58-65. 
Işık, C., \& Türkmendağ, T. (2016). Determinants of individual innovativeness perception of Atatürk university tourism faculty students. Gazi University Journal of Tourism Faculty, 70-99.

Karasar, N. (2015). Araştırmalarda rapor hazırlama [Preparing reports in researches]. Ankara: Nobel Academy Publications.

Karataş, S., \& Özcan, S. (2010). The effects of creative thinking activities on learners' creative thinking and project development skills. Ahi Evran University Kırşehir Journal of Education Faculty, 11(1), 225-243.

Kert, S. B., \& Tekdal, M. (2012). Comparison of the perception of innovation of individuals attending different education faculties. Gaziantep University Journal of Social Sciences, 11(4), 1150-1161.

Kılıç, H. (2015). İlköğretim branş ögretmenlerinin bireysel yenilikçilik düzeyleri ve yaşam boyu ögrenme ĕgilimleri: Denizli ili örneği [Individual innovation levels and lifelong learning trends of primary education teachers: Denizli province example] (Unpublished master thesis). Pamukkale University Institue of Educational Sciences, Denizli.

Kılıçer, K. (2011). Bilgisayar ve ögretim teknolojileri eğitimi ögretmen adaylarının bireysel yenilikçilik profilleri [Individual innovation profiles of pre-service teachers of computer and instructional technology education] (Unpublished doctoral thesis). Anadolu University Institue of Educational Sciences, Eskişehir.

Kılıçer, K., \& Odabaşı, H. F. (2010). Individual innovativeness scale (IS): The study of adaptation to Turkish, validity and reliability. Hacettepe University Journal of Education, 38(38), 150-164.

Korucu, A. T., \& Olpak, Y. Z. (2015). Examination of teacher candidates' individual innovativeness properties from the different variables. Educational Technology: Thaeory and Practice, 5(1), 11127.

Kozikoglu, İ. (2017). Prospective teachers' cognitive constructs concerning 1deal teacher qualifications: A phenomenological analysis based on repertory grid technique. International Journal of Instruction, 10(3), 63-78.

Köroğlu, A. Y. (2014). Okul öncesi öğretmenlerinin ve öğretmen adaylarının bilişim teknolojileri özyeterlik algıları, teknolojik araç-gereç kullanım tutumları ve bireysel yenilikçilik düzeylerinin incelenmesi [Investigation of information technologies self-efficacy perceptions, technological tools and equipment attitudes and individual innovation levels of pre-school teachers and prospective teachers] (Unpublished master thesis). Gazi University Institue of Educational Sciences, Ankara.

Lee, Y. J. (2011). A case study on the effect of technology innovation on learning effectiveness: Using a moderator of integrating information technology into teaching. The Journal of Human Resource and Adult Learning, 33-46.

Loogma, K., Kruusvall, J., \& Ümarik, M. (2012). E-learning as innovation: Exploring innovativeness of the VET teachers' community in Estonia. Computers \& Education, 58(2), 808-817.

Örün, Ö., Orhan, D., Dönmez, P., \& Kurt, A. A. (2015). Exploring the relationship between individual innovativeness and technology attitude of teacher candidates. Trakya University Journal of Education Faculty, 5(1), 65-76.

Özabac1, N., \& Acat, B. M. (2005). A comparative study of ideal and self characteristics of teacher candidates. Educational Administration: Theory and Practice, 11(2), 211-236.

Özerbaş, M. A. (2011). The effect of creative thinking teaching environment on academic achievement and retention of knowledge. Gazi University Journal of Education Faculty, 31(3), 675-705.

Özgenel, M., \& Çetin, M. (2017). Development of the Marmara creative thinking dispositions scale: Validity and reliability analysis. Journal of Educational Sciences, 46(46), 113-132. 
Özgür, H. (2013). Investigation of the relationship between critical thinking tendencies and individual innovativeness of information technologies prospective teachers in terms of various variables. Mersin University Journal of Education Faculty, 9(2), 409-420.

Richardson-Kemp, C., \& Yan, W. (2003). Urban school teachers' elf-efficacy beliefs and practices, innovation practices, and related factors in integrating technology. In Society for Information Technology \& Teacher Education International Conference (pp. 1073-1076). Association for the Advancement of Computing in Education (AACE).

Rogers, E. M. (2003). Diffusion of innovations. New York, A Division Macmillan Publishing.

Runco, M. A., \& Johnson, D. J. (2002). Parents' and teachers' implicit theories of children's creativity: A cross-cultural perspective. Creativity Research Journal, 14(3-4), 427-438.

Seechaliao, T. (2017). Instructional strategies to support creativity and innovation in education. Journal of Education and Learning, 6(4), 201-208.

Sönmez, S. (2004). The value of education and experience. Atatürk University Journal of Kazım Karabekir Education Faculty, 9, 351-364.

Stoltzfus, G., Nibbelink, B. L., Vredenburg, D., \& Hyrum, E. (2011). Gender, gender role, and creativity. Social Behavior and Personality: An International Journal, 39(3), 425-432.

Taylor, C. W., \& Sacks, D. (1981). Facilitating lifetime creative processes-A think piece. Gifted Child Quarterly, 25(3), 116-118.

Tok, E., \& Sevinç, M. (2012). The effects of thinking skills education on the creative thinking skills of preschool teacher candidates. Education and Science, 37(164), 204-222.

Torrance, E. P. (1965). Scientific views of creativity and factors affecting its growth. Daedalus, 663681.

Trilling, B., \& Fadel, C. (2009). 21st century skills: Learning for life in our times. San Francisco, CA, US: Jossey-Bass.

Tunca, N., Şahin, S. A., Oğuz, A., \& Güner, H. Ö. B. (2015). Qualities of ideal teacher educators. Turkish Online Journal of Qualitative Inquiry, 6(2), 122-148.

Ülger, K. (2016). The relationship between creative thinking and critical thinking skills of students. Hacettepe University Journal of Education, 31(4). 695-710.

Yaman, S., \& Yalçın, N. (2005). Effectiveness on creative thinking skills of problem based learning approach in science teaching. Elementary Education Online, 4(1), 42-52.

Yenilmez, K., \& Yolcu, B. (2007). Contributions of teachers' behaviors on creative thinking abilities. Journal of Social Sciences, 18, 95-105.

Yıldırım, A., \& Şimşek, H. (2013). Sosyal bilimlerde nitel araştırma yöntemleri [Qualitative research methods in the social sciences]. Ankara: Seçkin Publications.

Yıldız, L., Zırhlığlu, G., Yalçınkaya, M., \& Güven, Ş. (2011). Creativity and problem solving skills of physical education teacher candidates. Yüzüncü Yll University Journal of Education Faculty, 8, 18-36.

Yılmaz Öztürk, Z., \& Summak, M. (2015). Investigation of primary school teachers' individual innovativeness. International Journal of Science Culture and Sport, 2, 844-853.

Yılmaz, R., \& Beşkaya, Y. M. (2018). Investigation of lifelong learning trends and individual innovativeness level of education administrators. Ankara University Journal of Faculty of Educational Sciences, 51(1), 159-181.

Young, J. G. (1985). What is creativity?. The Journal Of Creative Behavior, 19(2), 77-87. 
